\title{
Institutional Effectiveness as a Tool in Creating Quality Assurance in Higher Education Management
}

\author{
${ }^{1}$ Sepideh Samadi, ${ }^{1}$ Poonam Singh, ${ }^{2}$ Ravikiran Dwivedula \\ ${ }^{1}$ American College of Dubai, UAE \\ ${ }^{2}$ Brandon University, Canada
}

\begin{abstract}
Organizations worldwide have been exploring ways to improve business practices to gain competitive edge. Usually the analysis of Quality Management deals with the technical and operational factors that can be implemented with the help of Institutional Effectiveness in every organization, also logistical aspects, especially in Education industry. The purpose of this case study is to present the importance of quality assurance in improving the administration of higher education institution. We use the academic program reaccreditation of the Bachelor of Business Administration program (BBA) of American College of Dubai, UAE as a case study. We first present the quality assurance framework of United Arab Emirates- QF Emirates. We then demonstrate the alignment of our program to the specific requirements of $Q F$ Emirates. The key components to this alignment include learner experience, teaching effectiveness, quality management processes, and institution's long-term goals, and strategy. Finally, we demonstrate the benefits of the re-licensure project to $A C D$.
\end{abstract}

\section{Introduction}

The global emerging trends in Higher Education (HE) has necessitates governmental and private policy makers to create an environment that supports high quality HE initiatives [7]. Such initiatives have significant implications for theory and practice specifically the growth in HE leads to development of Educational hubs or City Universities [1].

The purpose of this paper is to present the Quality Assurance process in Higher Education Institution and how the various organizational units contribute to the success of the Academic Programs. We specifically present the Bachelor of Business Administration program re-accreditation at the American College of Dubai as a case study. In addition, Institutional effectiveness is known as an efficient, explicit and documented with formalized process of measuring performance against mission in all aspects of an institution [2]. Institutions of higher learning are measured in terms of the organization's or the education industries' purpose, objectives consistent with industry's mission, documentation of student's achievement, and its use in improvement of educational programmes [6]. All elements of the system may not be taken at the same time or even annually, but it can be done at periodic intervals that make sense for the institution and its mission.

This study is organized as follows. First, we expand some literature reviews regarding Institutional Effectiveness in bringing quality into the organization and then introduce UAE's Quality Assurance Framework for Higher Education Programs-QFEmirates. Then we present a brief profile of American College of Dubai, as ACD is being used as a sample industry in order to show the effect of IE in creating quality. Afterward, we explain the quality assurance process at American College of Dubai. Subsequently, we present the successful reaccreditation of the BBA program at ACD which became successful by employing a great IE activities and implementation. Finally, we discuss the benefits of program re-accreditation to ACD. From the foregoing, literature supports the view that institutional effectiveness is a developmental process which allows measures [4]. Many institutions continue to face difficulties with incorporation of institutional effectiveness activities into their routine practice. The expertise and tools are not available in most of the universities.

\section{Institutional Effectiveness in Education Industry}

There is no definition of quality without using effectiveness. Welsh and Metcalf [11] argued that institutional effectiveness efforts are an important factor to compromise whilst faculty members, administrative and staff define quality differently. Institutional effectiveness efforts are compromise, 
when faculty administrators and staff have differing definitions of quality. Institutional effectiveness efforts become more meaningful and tangible when resources and inputs, in an organization are operational and outcomes are being assessed in an environment of common understanding and shared purpose [10]. Involvement of faculty, staff and administrators is a significant factor that goes creates a great meaning to institutional effectiveness. Much of literature addresses the need to garner more faculty involvement in institutional effectiveness activities [3], [11].

Using Institutional Effectiveness in education industry has a historical background and has been defined differently by each individual education industry. Other agencies might have required comparing colleges and universities, so the real definition of using IE was defined locally within the college or university [8]. During $20^{\text {th }}$ century, higher education industries in United States expanded a selfaccreditation processes which was being managed by the use of local and regional accreditation agencies. The purpose was to define some agreed-upon criteria for what might happen and occur in a college or university, reforming acceptable transfer from one institution to another, asks for faculty engagement, staff and administration in a regular review process [9]. Although there were different regional accrediting bodies morphed into similar agencies, they are still recognized common ground for keeping and maintaining a coherent definition of institutional effectiveness. During that time, most of the regional accrediting agencies have revised their accreditation criteria to include more purposeful and concise language about institutional effectiveness.

\section{Introduction to QF- Emirates}

The purpose of QFEmirates is to create a comprehensive and a Unified National Strategy for developing Qualifications in education that leads to better compliance with international accreditation bodies and creation of high-quality workforce for the country. The framework addresses policies, procedures and practices at all levels of educationschooling, K12, undergraduate and graduate levels.

The QFEmirates comprehensively and objectively compares all qualifications delivered in the United Arab Emirates; it specifically describes learning outcomes to be achieved in terms of knowledge, skills, and competence. These three strands of learning outcomes comprehensively cover cognitive abilities, application of knowledge to specific contexts, development of specific skills, and development of competence leading to demonstrable professional and personal development. Furthermore, successful achievement of these learning outcomes leads to significant enhancement of the schools profile. The description of the three dimensions is summarized in Table 1.

\section{ACD Goals/Objectives Matrix}

The quality assurance process at ACD is drawn from the institute's goals which are mapped to specific objectives of its units. Here, we consider the objectives of the Business department-BBA Program. The achievement of objectives is brought about by developing robust assessment tools and monitoring of the Unit's performance goals. The objectives of the BBA Program which include developing conceptual knowledge, career success skills and personal development, which in turn are aligned with the QFEmirates framework. This is summarized in Table 2.

\section{Quality Assurance at ACD-Re- Accreditation of BBA Program}

Going back to the beginning of the IE introduction in education industry, we learn a lesson from the history overview of IE in higher education. Bringing Institutional Effectiveness has become a major driver of data-intensive efforts to demonstrate and show the institution's effectiveness in all areas. The criteria and framework used for accreditation all over the country have become more sophisticated and useful to help support people, technology, culture and processes to support IE. These mechanisms can work better only when they are being properly leveraged through a good leadership. However, leaders might face discouraging task. As a result of this, the technology systems that can be used to support these efforts are not standardized across all technologies, and there is also no standard definition of what constitutes a modern "effective": educational institution.

The quality assurance process for the purpose of program re-accreditation requires the university to comprehensively evaluate each of its academic and administrative units. The first step to the reaccreditation process is the evaluation of the university's vision, mission, and goals that will direct its strategic initiatives for the consolidation and expansion of the BBA program. Organizational entities such as Business Advisory Committee, Alumni relations office, and office for community engagement are responsible for providing inputs such as the environmental opportunities, and challenges to the organization, and then to the program. 
Table 1. QFEmirates Framework

\begin{tabular}{|l|l|}
\hline Knowledge (K) & $\begin{array}{l}\text { Gained specialized knowledge, developed an understanding of theories } \\
\text { a developed a comprehensive understanding of methods and problem- } \\
\text { solving techniques, understand the critical approach to develop new } \\
\text { concepts, familiar with the latest research and current practices. }\end{array}$ \\
\hline Skills (S) & $\begin{array}{l}\text { Developed technical, analytical, and creative skills to solve problems, } \\
\text { developed skills to evaluate, select, and apply the appropriate methods } \\
\text { to solve problems and identify solutions and developed advanced } \\
\text { communication and information technology skills. }\end{array}$ \\
\hline $\begin{array}{l}\text { Autonomy } \\
\text { Responsibility } \\
\text { (AR) }\end{array}$ & $\begin{array}{l}\text { Take responsibility to develop and manage complex work procedures, } \\
\text { be able to manage technical or managerial work in complex work } \\
\text { environments, work effectively as an individual or a team member and } \\
\text { accept responsibility. }\end{array}$ \\
\hline $\begin{array}{l}\text { Role in Context } \\
\text { (RC) }\end{array}$ & $\begin{array}{l}\text { Be able to work independently without lot of supervision, take } \\
\text { responsibility for setting the goals and for other members of the team at } \\
\text { work, be able to collaborate with other qualified experts and work in } \\
\text { group and, take responsibility for professional development and } \\
\text { mentoring of individuals working in team. }\end{array}$ \\
\hline $\begin{array}{l}\text { Self-Development } \\
\text { (SD) }\end{array}$ & $\begin{array}{l}\text { Undertake regular professional development about new knowledge, be } \\
\text { able to learn new knowledge or while working and can contribute to } \\
\text { development of ethical standards and resolve ethical issues when } \\
\text { working. }\end{array}$ \\
\hline
\end{tabular}

Table 2. Assessment of Program Objectives

\begin{tabular}{|c|c|}
\hline OBJECTIVE & HOW ASSESSED \\
\hline $\begin{array}{l}\text { B1 To ensure degree offerings and component } \\
\text { coursework reflect the unique requirements of } \\
\text { regional business and industry. }\end{array}$ & $\begin{array}{ll}\text { - } & \text { Feedback from employers } \\
\text { - } & \text { Input from Business Community Advisory } \\
& \text { Board) } \\
\text { - } & \text { Alumni feedback }\end{array}$ \\
\hline $\begin{array}{l}B 2 \sim \text { To educate students to think logically and } \\
\text { critically in order to integrate relevant business } \\
\text { technology. }\end{array}$ & $\begin{array}{ll}\text { - } & \text { Student academic results (Capstone and } \\
\text { business project courses) } \\
\text { - } & \text { Feedback from employers } \\
\text { - } & \text { Alumni feedback }\end{array}$ \\
\hline $\begin{array}{l}\text { B3 To ensure an emphasis on creativity and } \\
\text { entrepreneurial spirit. }\end{array}$ & $\begin{array}{ll}\text { - } & \text { Student academic results } \\
\text { - } & \text { Postrepreneurship/related courses) } \\
\end{array}$ \\
\hline $\begin{array}{l}\text { B4 } \sim \text { Engage faculty and staff who will help } \\
\text { students develop the capacity to make appropriate } \\
\text { business-related decisions in a global environment. }\end{array}$ & $\begin{array}{ll}\text { - } & \text { Faculty supervisory/peer reviews and } \\
\text { classroom observations } \\
\text { - } & \text { Student feedback } \\
\text { - } & \text { Feedback from employers }\end{array}$ \\
\hline $\begin{array}{l}\text { B5 } \sim \text { Where applicable - to better prepare students } \\
\text { to manage family enterprises. }\end{array}$ & $\begin{array}{ll}\text { - } & \text { Student/alumni feedback } \\
\text { - } & \text { Assessment of related BBA coursework } \\
\end{array}$ \\
\hline $\begin{array}{l}\text { B6 } \sim \text { Research Activity: Ensure that all Business } \\
\text { faculty members are engaged in meaningful } \\
\text { research }\end{array}$ & $\begin{array}{l}\text { - Academic Research Committee reports and } \\
\text { IE review. }\end{array}$ \\
\hline
\end{tabular}




\begin{tabular}{|c|c|}
\hline $\begin{array}{l}\text { STUDENT SATISFACTION: Ensure that over } \\
85 \% \text { of students are satisfied with their BBA } \\
\text { coursework learning experience. }\end{array}$ & - $\quad$ Student Survey Data \\
\hline $\begin{array}{l}\text { STUDENT SATISFACTION. Ensure that over } \\
85 \% \text { of ex-students indicate their ACD BBA } \\
\text { coursework prepared them for upper level } \\
\text { coursework. }\end{array}$ & $\begin{array}{ll}- & \text { Student Survey Data }\end{array}$ \\
\hline $\begin{array}{l}\text { INSTRUCTOR PERFORMANCE. Achieve over } \\
80 \% \text { positive student feedback as regards instructor } \\
\text { performance. }\end{array}$ & $\begin{array}{ll} & \text { Student Survey Data }\end{array}$ \\
\hline $\begin{array}{l}\text { INSTRUCTOR PERFORMANCE. Achieve over } \\
90 \% \text { positive peer and/or supervisory assessment of } \\
\text { instructional performance. }\end{array}$ & $\begin{array}{ll} & \text { Peer Review Reports } \\
- & \text { Supervisory class observation/reports }\end{array}$ \\
\hline $\begin{array}{l}\text { INSTRUCTOR PERFORMANCE. Ensure } 100 \% \\
\text { compliance with mandated course syllabi } \\
\text { requirements. }\end{array}$ & - $\quad$ Supervisory Review \\
\hline
\end{tabular}

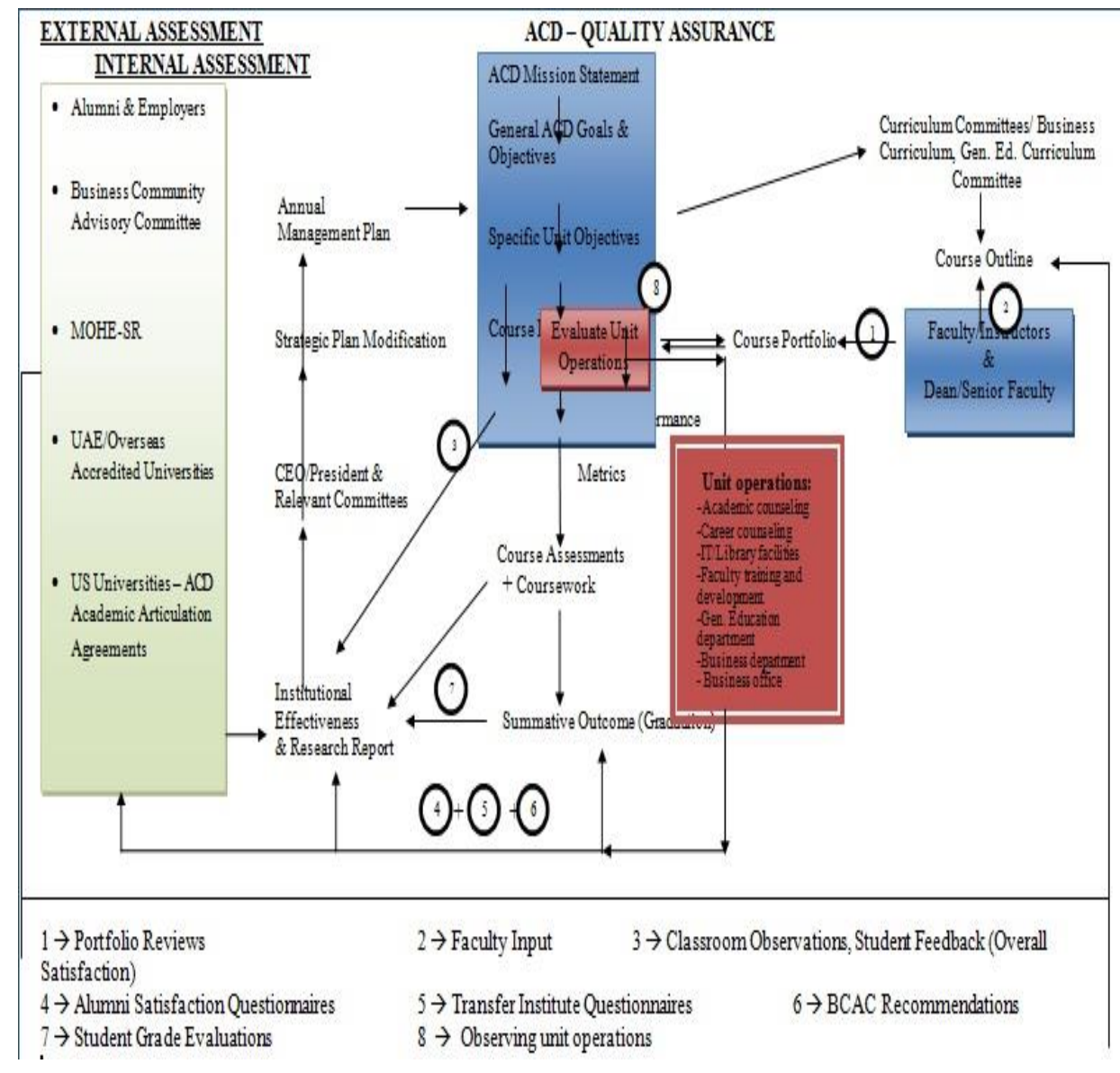

Figure 1. A summary of the quality assurance process

The office of President in coordination with the office of Pro-Vost is then responsible for providing direction to various organizational units to develop their objectives and to set up standing and ad-hoc 
committees that will oversee the achievement of these objectives by determining time-bound targets, identifying personnel/units responsible for achieving those targets, and constant monitoring of the unit's performance. The committees will comprehensively evaluate the program development and administration by using a variety of methods such as student coursework assessment, faculty portfolio review, effective support of learning management services (IT and Library services), feedback from partner universities where the students may have transferred to track student success, and employer feedback. Such information is collected, and analyzed by the Office of Institutional Research for program improvement. A summary of the quality assurance process followed for the purposes of program re-accreditation is presented in Figure 1.

\section{Conclusion}

In this study, we present the quality assurance process at American College of Dubai. Quality assurance is important for successful re-accreditation of the university's academic programs. We describe the contribution of various organizational units for this project. The successful re-accreditation of the BBA program has reinforced ACD's commitment to provide high quality business education leading to successful careers. Furthermore, the program reaccreditation has significantly improved the university's standing among its peers, higher student enrollment and increase revenue for the university.

\section{Reference}

[1] Beine, M., Noel, R., Ragot, L. (2014). Determinants of the international mobility of the students, Economics of Education Review, 41:40-54.

[2] Emory university resource manual, (2013) Office of institutional research planning and effectiveness.

[3] Klein, A., and Dunlop P., (1994) change faculty administrstion perspective. College student journal 28: 199-204.
[4] Koch R., Cairns, J.M., and Bunk, M., (2000). How to involve staff in developing an outcome oriented organization education and treatment of children 23 (i): 41-47.

[5] National Qualifications Authority, Qualifications Framework, 2018, Access: 20/01/2018, http://www.qualifications.ae/Qualifications_Framew ork\&sub=4

[6] Nichols and Nichols the department Heed's Guide to Assessment Implementation.

[7] Roglio, K. D. and G. Light (2009). 'Executive MBA programs: the development of the reflective executive', Academy of Management Learning and Education, 8(2), pp. 156-173.

[8] Roueche, J. E. et al. (1997). Embracing the tiger: The effectiveness debate and the community college. Washington, DC: American Association of Community Colleges.

[9] Roueche, J. E. et al. (2001). In pursuit of excellence: The community college of Denver. Washington, DC: American Association of Community Colleges.

[10] Sheldon, M.R; Golub, A.J; Langevin, J.R; st. ours, P.A and Swartzlander (2008) improving institutional effectiveness description new England, planning for higher education.

[11] Welsh J. F and Mecalf J. (2003) faculty and administrative support for institutional effectiveness activities. A bridge across the chasm? Journal of higher education 74(4) 44568 